\title{
Luminescent Three-co-ordinated Dinuclear Copper(1) Complexes of Bis(diphenylphosphino)methane: Photophysical Properties and Crystal Structure
}

\author{
Dan Li," Chi-Ming Che,",a Wing-Tak Wong, Shen-Jye Shieh ${ }^{b}$ and Shie-Ming Peng ${ }^{b}$ \\ a Department of Chemistry, University of Hong Kong, Pokfulam Road, Hong Kong \\ ${ }^{b}$ Department of Chemistry, National Taiwan University, Taipei, Taiwan
}

Reaction between $\left[\mathrm{Cu}_{2}(\mu-d p p m)_{2}(\mathrm{MeCN})_{4}\right]^{2+}[\mathrm{dppm}=$ bis(diphenylphosphino)methane $]$ and substituted pyridines or triphenylphosphine $(\mathrm{L})$ in dichloromethane gave products $\left[\mathrm{Cu}_{2}(\mu-\mathrm{dppm})_{2} \mathrm{~L}_{2}\right]^{2+}$ which possess long-lived emissive electronic excited states in fluid solution at room temperature.

The study of the photoluminescent properties of $\mathrm{d}^{10}$ metal complexes has been receiving current attention. ${ }^{1-9} \mathrm{~A}$ number of polynuclear complexes of $\mathrm{Au}^{1,2 a, b, d, f, 5 c, 6,8} \mathrm{Ag}^{12 c, d}$ and $\mathrm{Cu}^{12 e}$ containing bridging phosphine ligands have been reported which show intriguing photophysical and photochemical properties. We have also investigated the spectroscopic properties of $\left[\mathrm{Cu}_{2}(\mu \text {-dppm })_{2}(\mathrm{MeCN})_{4}\right]\left[\mathrm{ClO}_{4}\right]_{2}[\mathrm{dppm}=$ bis(diphenylphosphino)methane ${ }^{2 g}$ which has also been found to be emissive in fluid solutions. Herein is described the synthesis and spectroscopic properties of complexes $\left[\mathrm{Cu}_{2}(\mu-\mathrm{dppm})_{2} \mathrm{~L}_{2}\right]$ $\left[\mathrm{ClO}_{4}\right]_{2}\left[\mathrm{~L}=\mathrm{PPh}_{3}\right.$, pyridine (py), or 4-substituted pyridines $\mathrm{X}$-py, where $\mathrm{X}=4-\mathrm{ClC}_{6} \mathrm{H}_{4} \mathrm{CH}=\mathrm{CH}\left(\mathrm{L}^{1}\right), 4-\mathrm{O}_{2} \mathrm{NC}_{6} \mathrm{H}_{4} \mathrm{CH}_{2}$ $\left(\mathrm{L}^{2}\right), \mathrm{PhCH}=\mathrm{CH}\left(\mathrm{L}^{3}\right)$ or $\left.\mathrm{Me}\left(\mathrm{L}^{4}\right)\right]$ and the crystal structure of the complex with $\mathrm{L}^{1}$. We have found that the co-ordinated acetonitrile in $\left[\mathrm{Cu}_{2}(\mu-\mathrm{dppm})_{2}(\mathrm{MeCN})_{4}\right]\left[\mathrm{ClO}_{4}\right]_{2}$ is substitutionally labile and is easily replaced by nitrogen bases. This work provides a new entry to donor-acceptor supramolecules based on the $\left[\mathrm{Cu}_{2}(\mu \text {-dppm })_{2}(\mathrm{py})_{2}\right]^{2+}$ luminophore.

The precursor complex $\left[\mathrm{Cu}_{2}(\mu-\mathrm{dppm})_{2}(\mathrm{MeCN})_{4}\right]\left[\mathrm{ClO}_{4}\right]_{2}$ was prepared by the literature method. ${ }^{10}$ Treatment of $\left[\mathrm{Cu}_{2}(\mu-\right.$ dppm $\left.)_{2}(\mathrm{MeCN})_{4}\right]\left[\mathrm{ClO}_{4}\right]_{2}(0.1 \mathrm{~g})$ with an excess of ligand $\mathrm{L}(0.1$ $\mathrm{g}$ ) in dichloromethane $\left(30 \mathrm{~cm}^{3}\right)$ at room temperature for $15 \mathrm{~min}$ afforded the crystalline complexes $\left[\mathrm{Cu}_{2}(\mu-\mathrm{dppm})_{2} \mathrm{~L}_{2}\right]\left[\mathrm{ClO}_{4}\right]_{2}$ in high yield $(>70 \%$ ) upon precipitation with diethyl ether. The complexes were recrystallised by diffusion of diethyl ether into acetone solutions. These species have been characterised by Xray crystallography, ${ }^{11}+\dagger$ and elemental analyses.

Fig. 1 shows a perspective view of the cation in $\left[\mathrm{Cu}_{2}(\mu-\right.$ dppm $\left.)_{2} \mathrm{~L}_{2}^{1}\right]\left[\mathrm{ClO}_{4}\right]_{2}$ 1. The co-ordination geometry around each copper atom is trigonal planar with bonding to two $P$ and one $\mathrm{N}$ atom. The two copper atoms are doubly bridged by two $\mathrm{dppm}$ ligands and the two nitrogen ligands are co-ordinated to separate metal atoms at opposite ends of the structure. In contrast to $\left[\mathrm{Au}(\mathrm{dppm})_{2}\right]^{2+2 a, b, 6}$ in which a metal-metal

† Crystal data for $\left[\mathrm{Cu}_{2}(\mu-\mathrm{dppm})_{2} \mathrm{~L}_{2}^{1}\right]\left[\mathrm{ClO}_{4}\right]_{2}$ 1: $\mathrm{C}_{76} \mathrm{H}_{64} \mathrm{Cl}_{4} \mathrm{Cu}_{2} \mathrm{~N}_{2} \mathrm{O}_{8} \mathrm{P}_{4}$ $M=1526.2$, triclinic space group $P \mathrm{I}^{2}(\mathrm{no}, 2), a=10.421(4), b=17.745(6), c=$ $M=1526.2$, triclinic space group $P I$ (no. 2$), a=10.421(4), b=17.745(6), c=$
$20.014(8) \AA, \alpha=93.03(3), \beta=99.95(3), \gamma=98.52(3)^{\circ}, U=3593 \AA^{3}, Z=2$, $D_{\mathrm{c}}=1.441 \mathrm{~g} \mathrm{~cm}^{-3}, \mu\left(\mathrm{Mo}-\mathrm{K}_{\alpha}\right)=8.85 \mathrm{~cm}^{-1}, F(000)=1568$, no. of variables 455 , no. of unique data measured 6650 , no. of observed data with $\left|F_{\mathrm{o}}\right| \geqslant 3 \sigma\left|F_{\mathrm{o}}\right| 5075$, $R\left(=\Sigma|| F_{\mathrm{o}}|-| F_{\mathrm{c}} \| / \Sigma\left|F_{\mathrm{o}}\right|\right)=0.069, \quad R^{\prime}\left(=\Sigma w\left(\left|F_{\mathrm{o}}\right|-\left|F_{\mathrm{c}}\right|\right)^{2} / \Sigma w\left|F_{\mathrm{o}}\right|^{2}\right]^{t}=0.091$ Weighting scheme $w=4 F_{0}^{2} /\left[\sigma^{2}\left(F_{0}{ }^{2}\right)+\left(0.04 F_{0}^{2}\right)^{2}\right]$. The residual extrema in the final difference map were 0.69 and $-0.51 \mathrm{e}^{-3}$. Intensity data were collected on an Enraf-Nonius CAD4 diffractometer with graphite-monochromated Mo-K $\alpha$ radiation $(0.71073 \AA)$ at room temperature $(298 \mathrm{~K})$. The structure was solved by a combination of Patterson and direct methods. Refinement was by full-matrix least squares. A perchlorate ion was found to be highly disordered. All computations were performed on a MicroVax II computer using Enraf-Nonius SDP programs. ${ }^{12}$ Atomic coordinates, thermal parameters and bond lengths and programs. ${ }^{2}$ Atomic coordinates, thermal parameters and bond lengths and Instructions for Authors, J. Chem. Soc., Dalton Trans., 1993, Issue 1, pp. xxiiixxviii. interaction is present, the $\mathrm{Cu} \cdot . \mathrm{Cu}$ separation in $\mathbf{1}$ is greater than $3.7 \AA$ indicating the absence of such an interaction. The $\mathrm{Cu}-\mathrm{N}$ bond lengths, 2.063(7) and 2.072(7) $\AA$, are practically identical to those found in $\left[\mathrm{Cu}_{2}(\mu-\mathrm{dppm})_{2}(\mathrm{MeCN})_{4}\right]\left[\mathrm{ClO}_{4}\right]_{2} \cdot{ }^{10}$ The co-ordinated ligand $L^{1}$ does not adopt a planar configuration.

The spectroscopic data for the copper complexes are summarized in Table 1. Fig. 2 shows the electronic absorption and emission spectra of $\left[\mathrm{Cu}_{2}(\mu-\mathrm{dppm})_{2} \mathrm{~L}_{2}{ }_{2}\right]\left[\mathrm{ClO}_{4}\right]_{2}, 1,\left[\mathrm{Cu}_{2}(\mu-\right.$ dppm $\left.)_{2}(\mathrm{py})_{2}\right]\left[\mathrm{ClO}_{4}\right]_{2} 2$ and $\left[\mathrm{Cu}_{2}(\mu-\mathrm{dppm})_{2} \mathrm{~L}_{2}{ }_{2}\right]\left[\mathrm{ClO}_{4}\right]_{2} 3$ in dichloromethane at room temperature. The absorption spectra of 2 and 3 exhibit a broad shoulder absorption between 300 and $350 \mathrm{~nm}$ with $\varepsilon_{\max } \approx 1 \times 10^{3} \mathrm{dm}^{3} \mathrm{~mol}^{-1} \mathrm{~cm}^{-1}$, which is similar to that of $\left[\mathrm{Cu}_{2}(\mu-\mathrm{dppm})_{2}(\mathrm{MeCN})_{4}\right]\left[\mathrm{ClO}_{4}\right]_{2}$ and probably arises from a metal-perturbed intraligand $\pi \longrightarrow \pi^{*}$ transition of co-ordinated phosphine. The absorption spectrum of 1 is dominated by a more intense absorption band at $\lambda_{\max } 315 \mathrm{~nm}\left(\varepsilon_{\max }=4.19 \times 10^{4} \mathrm{dm}^{3} \mathrm{~mol}^{-1} \mathrm{~cm}^{-1}\right)$. Since this band is also found in the absorption spectrum of the free ligand, $\mathrm{L}^{1}$, this is assigned to the intraligand $\pi \longrightarrow \pi^{*}$ transition of $\mathrm{L}^{1}$.

The complexes exhibit photoluminescence both in the solid state or in fluid solution $\left(\mathrm{CH}_{2} \mathrm{Cl}_{2}\right)$ at room temperature. Excitation in the range $300-360 \mathrm{~nm}$ of degassed dichloromethane solutions of the complexes gives emission at ca. $520 \mathrm{~nm}$. The free ligand dppm also displays emission at $500 \mathrm{~nm}$ in dichloromethane upon excitation in the range $300-350 \mathrm{~nm}$. The emission maximum at $520 \mathrm{~nm}$ of the complexes is considerably red shifted from that of dppm. A similar red shift in energy was also found in $\left[\mathrm{Cu}(\mathrm{dppe})\left(\mathrm{BH}_{4}\right)\right][\mathrm{dppe}=1,2-\mathrm{bis}$ (diphenylphosphino)ethane] ( $537 \mathrm{~nm}$ emission vs. the $500 \mathrm{~nm}$ emission of free dppe) by Kutal and co-workers. ${ }^{9}$ In the emission spectrum of 1 a weak high-energy peak appears at $450 \mathrm{~nm}$. An intraligand $\pi \longrightarrow \pi^{*}$ state is suggested as an analogous band is observed in the emission spectrum of free $L^{1}$. The photophysical properties of the complexes $\left[\mathrm{Cu}_{2}(\mu-\mathrm{dppm})_{2} \mathrm{~L}_{2}\right]\left[\mathrm{ClO}_{4}\right]_{2}$ are summarized in Table 1 . Life-times were obtained by singleexponential decay fitting. It is interesting that the emission lifetime $(0.4 \mu \mathrm{s})$ of $\left[\mathrm{Cu}_{2}(\mu-\mathrm{dppm})_{2}(\mathrm{MeCN})_{4}\right]\left[\mathrm{ClO}_{4}\right]_{2}$ is significantly shorter than the values $(\geqslant 24 \mu \mathrm{s})$ of related complexes containing nitrogen bases or $\mathrm{PPh}_{3}$ as axial ligands. It has been reported ${ }^{10}$ that the acetonitrile ligands in $\left[\mathrm{Cu}_{2}(\mu-\mathrm{dppm})_{2-}\right.$ $\left.(\mathrm{MeCN})_{4}\right]\left[\mathrm{ClO}_{4}\right]_{2}$ are in a fast dissociation equilibrium in fluid solution. This fast on-off co-ordination is not likely to occur for better donor ligands, such as pyridine or triphenylphosphine, leading to longer emission lifetimes.

The co-ordination of pyridine and its substituted derivatives or triphenylphosphine to $\left[\mathrm{Cu}_{2}(\mu \text {-dppm })_{2}\right]^{2+}$ results in the formation of dinuclear complexes having extraordinarily longlived excited states. Since the structure of the auxiliary nitrogen base or phosphine is easily tunable, this work may provide an 


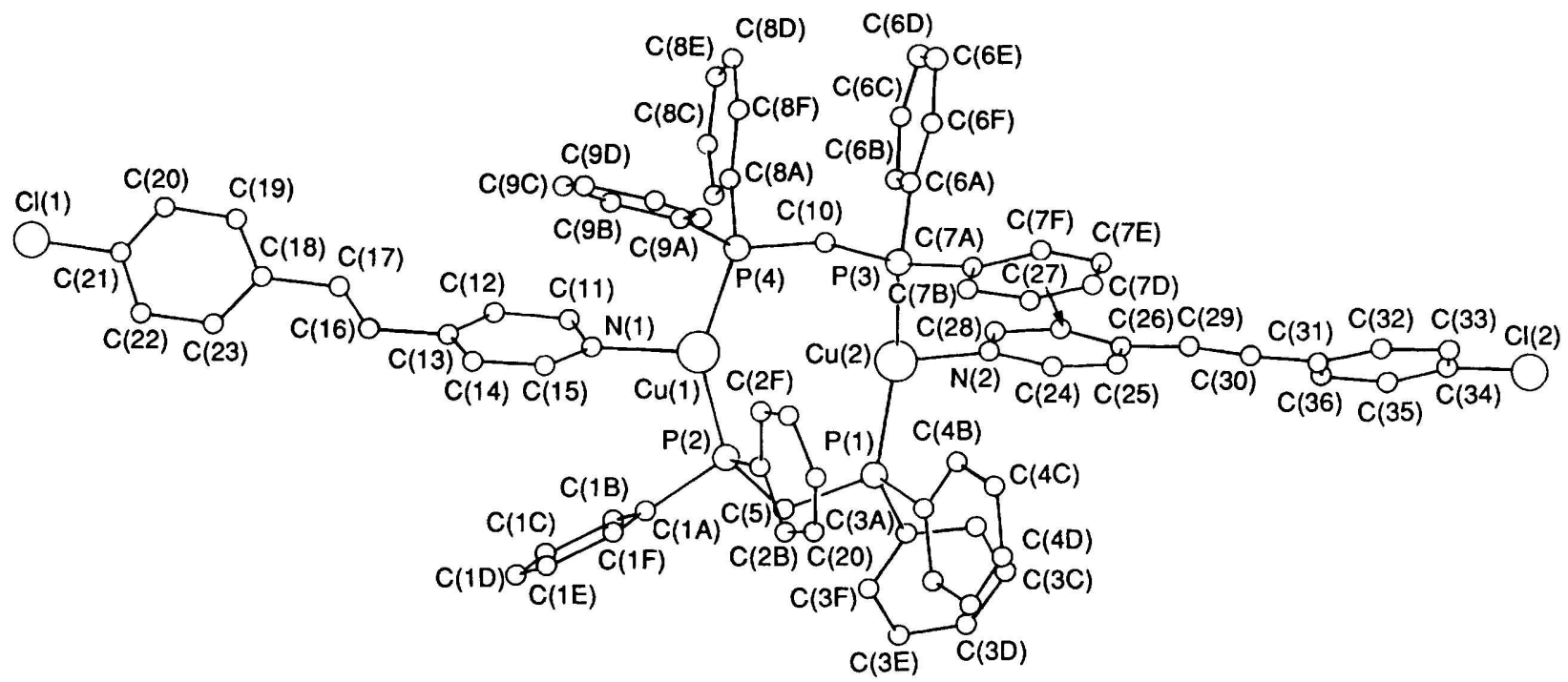

Fig. 1 A perspective view of the $\left[\mathrm{Cu}_{2}(\mu-\mathrm{dppm})_{2} \mathrm{~L}^{1}{ }_{2}\right]^{2+}$ cation. Selected bond lengths $(\AA)$ and angles $\left({ }^{\circ}\right): \mathrm{Cu}(1)-\mathrm{N}(1) 2.063(7), \mathrm{Cu}(1)-\mathrm{P}(2) 2.237(3)$, $\mathrm{Cu}(1)-\mathrm{P}(4)$ 2.229(2), $\mathrm{Cu}(2)-\mathrm{N}(2) \quad 2.072(7), \mathrm{Cu}(2)-\mathrm{P}(1)$ 2.272(2), $\mathrm{Cu}(2)-\mathrm{P}(3)$ 2.275(2), $\mathrm{P}(2)-\mathrm{Cu}(1)-\mathrm{P}(4)$ 131.7(2), $\mathrm{P}(2)-\mathrm{Cu}(1)-\mathrm{N}(1) 110.2(2)$, $\mathrm{P}(4)-\mathrm{Cu}(1)-\mathrm{N}(1)$ 108.7(2), $\mathrm{P}(1)-\mathrm{Cu}(2)-\mathrm{P}(3)$ 137.0(1), $\mathrm{P}(1)-\mathrm{Cu}(2)-\mathrm{N}(2)$ 108.5(2), $\mathrm{P}(2)-\mathrm{Cu}(2)-\mathrm{N}(2)$ 101.4(2)

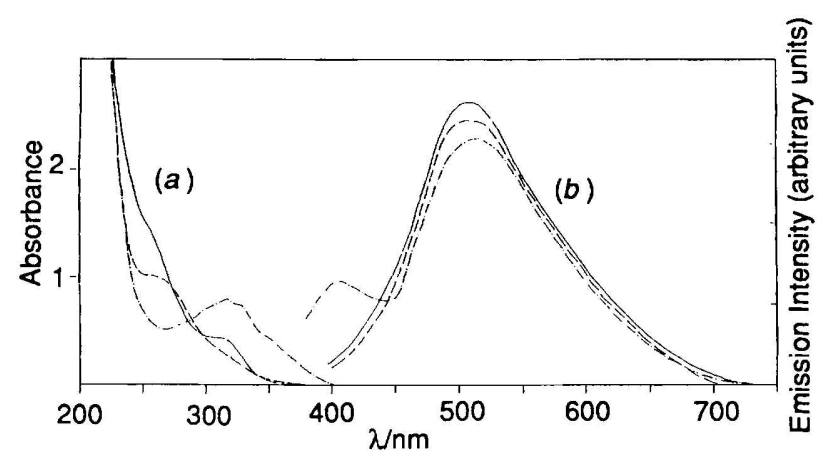

Fig. 2 UV/VIS absorption $(a)$ and emission spectra $(b)$ of $\left[\mathrm{Cu}_{2}(\mu-\right.$ dppm $\left.)_{2}(\mathrm{py})_{2}\right]\left[\mathrm{ClO}_{4}\right]_{2} 2(--),\left[\mathrm{Cu}_{2}(\mu-\mathrm{dppm})_{2} \mathrm{~L}^{2}{ }_{2}\right]\left[\mathrm{ClO}_{4}\right]_{2} 3(---)$ and $\left[\mathrm{Cu}_{2}(\mu-\mathrm{dppm})_{2} \mathrm{~L}_{2}{ }_{2}\right]\left[\mathrm{ClO}_{4}\right]_{2} 1(-\cdots)$

Table 1 Photophysical properties of complexes $\left[\mathrm{Cu}_{2}(\mu \text {-dppm })_{2} \mathrm{~L}_{2}\right]$ $\left[\mathrm{ClO}_{4}\right]_{2}$ in dichloromethane at room temperature

\begin{tabular}{|c|c|c|c|c|c|c|}
\hline $\mathrm{L}$ & $\lambda_{\mathrm{abs}} / \mathrm{nm}$ & $\begin{array}{l}\varepsilon / \mathrm{dm}^{3} \\
\mathrm{~mol}^{-1} \mathrm{~cm}^{-1}\end{array}$ & $\lambda_{\mathrm{em}} / \mathrm{nm}$ & $\tau / \mu \mathrm{s}^{a}$ & & $\Phi_{\mathrm{em}}^{b}$ \\
\hline $\mathrm{MeCN}^{c}$ & 314 & $1.12 \times 10^{4}$ & 530 & 0.4 & & $1.0 \times 10^{-4}$ \\
\hline $\mathrm{PPh}_{3}$ & $\begin{array}{l}255 \\
310(\mathrm{sh})^{d}\end{array}$ & $\begin{array}{l}3.00 \times 10^{4} \\
4.76 \times 10^{3}\end{array}$ & 550 & 75 & & $3.4 \times 10^{-2}$ \\
\hline py & 306 & $8.54 \times 10^{3}$ & 525 & 27 & & $1.8 \times 10^{-3}$ \\
\hline $\mathrm{L}^{1}$ & 315 & $4.19 \times 10^{4}$ & $\begin{array}{l}425 \\
525\end{array}$ & $\begin{array}{l}0.2 \\
51\end{array}$ & ! & $5.9 \times 10^{-4}$ \\
\hline 2 & $\begin{array}{l}255 \\
315(\mathrm{sh})\end{array}$ & $\begin{array}{l}4.88 \times 10^{4} \\
1.33 \times 10^{4}\end{array}$ & 515 & 24 & & $3.4 \times 10^{-3}$ \\
\hline $\mathbf{L}$ & 312 & $4.21 \times 10^{4}$ & $\begin{array}{l}424 \\
525\end{array}$ & $\begin{array}{l}0.2 \\
30\end{array}$ & & $6.1 \times 10^{-5}$ \\
\hline & 308 & $9.14 \times 10^{3}$ & 525 & 45 & & $1.0 \times 10^{-3}$ \\
\hline
\end{tabular}

${ }^{a}$ Emission life-time. ${ }^{b}$ Emission quantum yield. ${ }^{c}$ Four ligands are coordinated to two copper atoms. ${ }^{d}$ sh $=$ Shoulder.

entry into a new class of donor-acceptor supramolecules for studies of intramolecular photo-induced energy and electrontransfer reactions.

\section{Acknowledgements}

We acknowledge support from the Hong Kong Research Grants Council, the University of Hong Kong and the Croucher Foundation. C. M. C. and D. L. are grateful for a visiting professorship and a scholarship administered by the National Taiwan University and $\mathrm{Li} \mathrm{Ka}$ Shing Foundation, respectively.

\section{References}

1 D. R. McMillin, J. R. Kirchhoff and K. V. Goodwin, Coord. Chem. Rev., 1985, 64, 83; D. J. Casadonte and D. R. McMillin, J. Am. Chem. Soc., 1987, 109, 331; D. J. Casadonte and D. R. McMillin, Inorg. Chem., 1987, 26, 3950.

2 (a) C. M. Che, W. T. Wong, T. F. Lai and H. L. Kwong, J. Chem. Soc, Chem. Commun., 1989, 243; (b) C. M. Che, H. L. Kwong, C. K. Poon and V.W. W. Yam, J. Chem. Soc., Dalton Trans., 1990, 3215; (c) C. M. Che, H. K. Yip, D. Li, S. M. Peng, G. H. Lee, Y. M. Wong and S. T. Liu, J. Chem. Soc., Chem. Commun., 1991, 1615; (d) C. M. Che, H. K. Yip, V. W. W. Yam, P. Y. Cheung, T. F. Lai, S. J. Shieh and S. M. Peng, J. Chem. Soc., Dalton Trans., 1992, 427; (e) D. Li, H. K. Yip, C. M. Che, Z. Y. Zhou, T. C. W. Mak and S. T. Liu, J. Chem. Soc., Dalton Trans., 1992, 2445; $(f)$ D. Li, C. M. Che, S. M. Peng, S. T. Liu, Z. Y.Zhou and T.C.W. Mak, J. Chem. Soc., Dalton Trans.,1993, 189; (g) D. Li, C. M. Che, H. L. Kwong and V. W. W. Yam, J. Chem. Soc., Dalton Trans., in the press.

3 A. Vogler and H. Kunkely, Chem. Phys. Lett., 1988, 150, 135; 1989, 158, 135; 1989, 164, 621; J. Am. Chem. Soc., 1989, 108, 7211.

4 M. Henary and J. I. Zink, J. Am. Chem. Soc., 1989, 111, 7407; Inorg. Chem., 1991, 30, 3111 .

5 (a) P. D. Harvey and H. B. Gray, J. Am. Chem. Soc, 1988, 110, 2145; (b) P. D. Harvey, F. Adar and H. B. Gray, J. Am. Chem. Soc., 1989, 111, 1312; (c) T. M. McCleskey and H. B. Gray, Inorg. Chem., 1992, 31, 1733.

6 C. King, J. C. Wang, N. I. Khan Md and J. P. Fackler, jun., Inorg. Chem., 1989, 28, 2145; N. I. Khan Md, C. King, D. D. Heinrich, J. P. Fackler, jun. and L. C. Porter, Inorg. Chem., 1989, 28, 2150

7 K. R. Kyle, J. A. Dibenedetto and P. C. Ford, J. Chem. Soc., Chem. Commun., 1989, 714; K. R. Kyle, C. K. Ryu, J. A. Dibenedetto and P. C. Ford, J. Am. Chem. Soc., 1991, 113, 2954.

8 A. L. Balch, E. Y. Fung and M. M. Olmstead, J. Am. Chem. Soc., $1990,112,5181$.

9 P. A. Grutsch and C. Kutal, J. Am. Chem. Soc., 1979, 101, 4228; D. P. Segers, M. K. DeArmond, P. A. Grutsch and C. Kutal, Inorg. Chem., 1984, 23, 2874

10 J. Diez, M. P. Gamasa, J. Gimeno, A. Tiripicchio and M. T. Camellini, J. Chem. Soc., Dalton Trans., 1987, 1275.

11 S. J. Shieh, Master Thesis, National Taiwan University, 1992.

12 Enraf-Nonius Structure Determination Packages, SDP, EnrafNonius, Delft, 1985.

Received 22nd October 1992; Communication 2/05643G 